\title{
María en la religiosidad popular colombiana. Fenomenología religiosa y hermenéutica teológica*
}

\author{
P. Pedro José Díaz Camacho, O. P.**
}

\section{Resumen}

La presente investigación trata sobre el culto y la devoción mariana en el contexto de la religiosidad popular en Colombia, desde el punto de vista de la fenomenología religiosa y la hermenéutica teológica. este escrito describe y analiza las principales advocaciones y fiestas marianas, las imágenes y santuarios, las prácticas populares de piedad mariana y otros elementos que componen este importante rasgo de la religiosidad popular. Igualmente, estudia algunos elementos teológicos para una interpretación crítica de la devoción mariana popular, especialmente los aspectos cristológicos y eclesiales implicados para establecer y reconocer el sentido cristiano

* Díaz Camacho, P. J. (2012, 19 de sep.). Conferencia. en III Congreso Internacional de Teología Mariana. Chiquinquirá, BOy: Facultad de Teología de la Universidad Santo Tomás.

** Doctor en Teología por la Universidad Pontificia de Salamanca (España). Experto en estudios ecuménicos por la Universidad de San Buenaventura y del Celam. es fraile dominico colombiano y actualmente decano de la División de Ingenierías de la Universidad Santo Tomás (Bogotá).Correo electrónico: fraypedrodiaz@usantotomas.edu.co 
de la piedad mariana teniendo en cuenta las orientaciones del magisterio de la Iglesia después del Concilio Vaticano Segundo.

Palabras clave: religiosidad popular, piedad mariana, advocaciones marianas, devociones, fiestas, santuarios, peregrinaciones, fenomenología religiosa, hermenéutica teológica.

\section{Introducción: María y la devoción mariana en el contexto popular colombiano}

Desde el principio de la historia religiosa y cristiana, la figura de María ha sido uno de los signos configurativos, representativos e identificadores de mayor relieve en el campo de lo espiritual tanto en el caso del pueblo colombiano como, por supuesto, del latinoamericano. el catolicismo popular colombiano es mariano en sus más profundas raíces y la devoción de la Virgen es uno de sus rasgos más característicos. La identidad religiosa del pueblo casi se confunde con la piedad mariana: Colombia es, en lo religioso, un país mariano, se ha dicho con sobrada razón.

Los historiadores nos dicen que, desde los primeros esfuerzos de evangelización de lo que hoy es Colombia, "la figura de María", incluso físicamente, estuvo asociada a la obra misionera, "junto con la Cruz y la eucaristía": los predicadores, desde las primeras horas de la evangelización hasta los tiempos actuales, han introducido también las primeras imágenes de María, y la devoción a la Virgen ha formado parte fundamental de sus métodos misioneros. Una de esas primeras imágenes llegadas a Colombia es la de Nuestra Señora del Rosario de la Conquista, que se venera actualmente en el templo de Santo Domingo de Bogotá ${ }^{1}$, y entre las devociones asociadas a la evangelización y a la piedad popular ha ocupado un lugar de preferencia el Rosario, hasta el punto de que "no rezar el rosario era signo de poca o de ninguna cristiandad" (Cárdenas, 2004, p. 623).

1 Cfr., Ariza (1956); De Santa Teresa (1942); Mesanza (1950); Vargas Ugarte (1956). 
La herencia mariana proveniente de españa parece haber encontrado suelo nutricio y fecundo tanto en la sensibilidad religiosa de los aborígenes como en el valor simbólico de algunas deidades, mitos y cultos femeninos que configuraban su experiencia religiosa y que, por cierta afinidad, entraron en rápida sintonía con la devoción mariana ${ }^{2}$. Así lo expresa, por ejemplo, Gerardo Farrel, al decir que

la presencia de María en el origen y desarrollo histórico de América Latina es obra de los agentes pastorales venidos de españa, pero también es fruto de los pueblos nativos que la asumieron y en alguna medida la recrearon desde su realidad cultural $\left(1982\right.$, p. 535) ${ }^{3}$.

esta esencial connotación mariana del catolicismo popular colombiano se ha desarrollado y expresado sociohistóricamente a través de diferentes prácticas, símbolos, objetos y hechos de tipo devocional, cuya fenomenología y significado es preciso estudiar. A algunos de sus aspectos más significativos queremos dedicar en seguida nuestra atención. Conscientes de que es un tema amplio y que solamente podremos proponer una visión somera, la exposición se centrará especialmente en los aspectos culturales y devocionales. Debemos tener en cuenta, además, que la lectura teológica de este tema se ha de hacer en relación de continuidad con otros temas teológicos (Dios, Cristo, los sacramentos, la Iglesia, los santos, la escatología) a fin de mantener su sentido cristológico, eclesial y pastoral.

2 Para algunos aspectos de la mitología aborigen colombiana, cfr., Izquierdo Gallo (1956, pp. 44, 219-292).

3 Cfr., Alliende (1978); Pacheco (1975); “María en...” (1973); Dussel (CEHILA, I/1,582584). Un hermoso símbolo artístico religioso que testimonia la herencia mariana legada por españa a los pueblos americanos se halla expresado en la imagen de Santa María de la Rábida, cuya corona está formada con los escudos de todos los países hispanoamericanos; también es simbólicamente importante en este sentido la coincidencia de la fecha del Descubrimiento (12 de octubre) con la fiesta de la Virgen del Pilar, así como la existencia de santuarios homónimos en españa e Hispanoamérica. Véase el término Santuarios en Aldea Vaquero, Marín Martínez, y Vives Gatell (1972-1975, IV, 2207-2381), que reseña 487 santuarios, la mayoría marianos. 


\section{Aproximación fenomenológica al culto y a la devoción popular a la Virgen}

el tratamiento y desarrollo literario general que se ha dado en Colombia a la cuestión mariana ha producido un material editado bastante disperso, complejo y fragmentario, centrado en gran parte en el campo propiamente literario y en el de la pastoral de tipo devocional. Su estudio daría para una sugestiva e interesante investigación y para descubrir el poco interés propiamente teológico de la cuestión mariana entre quienes han cultivado las ciencias sagradas en Colombia. Podemos decir que tenemos un vacío teológico en este campo, el cual se va llenando con este tipo de eventos académicos.

Ateniéndonos al campo propiamente hermenéutico en torno al culto y a la devoción mariana de tipo popular, vamos a estudiar, desde una perspectiva fenomenológica primero, algunos elementos constitutivos y factores determinantes de la piedad popular mariana, teniendo en cuenta y reconociendo positivamente lo que otros han escrito en relación con este asunto ${ }^{4}$. Más adelante abordaremos aspectos teológicos y su interpretación.

\section{Advocaciones y fiestas marianas}

Las advocaciones y fiestas marianas que el pueblo colombiano conoce y celebra han experimentado un proceso dialéctico de difusión y arraigo, de crisis y recuperación, de olvido y transformación, condicionado por diversos factores sociopastorales, espirituales y doctrinales a lo largo de la historia y de la geografía patria. Como lo reconocía Paulo VI en la exhortación Marialis Cultus [MC], "la veneración de los fieles hacia la Madre de Dios ha tomado

4 Tenemos especialmente en cuenta las siguientes obras, además de las citadas en las notas anteriores: Caravias (1978, pp. 116-123); zuluaga (1977, pp. 43-46); Llano Ruiz (1982, pp. 44-51, 59-60 y 105-133); Restrepo (1972, pp. 75-77 y 182); Celam (1977, nn. 161-168 y 180-182); CEC (1969); Puebla (1979, nn. 282-303 y 844); Prien (1985, pp. 269-299). Sobre la significación de “culto y devoción" en relación con María, cfr., Martín Velasco (1984). Para cuestiones generales sobre la historia del culto mariano, cfr. Danemarie y Revilla (1960); Pozo (s.f.). 
formas diversas según las circunstancias de lugar y tiempo, la distinta sensibilidad de los pueblos y su diferente tradición cultural" (24).

Los primeros misioneros del pueblo neogranadino (hoy colombiano) traían no solamente algunos conceptos teológicos sobre la Virgen Maria y su puesto dentro del misterio cristiano, sino también determinada experiencia espiritual, devocional y pastoral en torno a la figura de María, que fueron difundiendo a través de diferentes prácticas de piedad. Los miembros de institutos religiosos traían las devociones de sus comunidades y propagaban aquellas advocaciones marianas que les eran familiares, así como otros aspectos propios de su espiritualidad ${ }^{5}$. Las principales advocaciones marianas arraigadas históricamente en el pueblo colombiano han sido las de la Virgen del Rosario, la Virgen del Carmen y la Inmaculada Concepción. La primera difundida particularmente por los dominicos, la segunda por los carmelitas y la tercera por los franciscanos, aunque no de manera exclusiva.

La Virgen del Carmen ha tenido especial significación devocional para el gremio de los conductores, que suelen llevar su imagen en los vehículos y participar muy activamente en la celebración de la fiesta (16 de julio) que tradicionalmente es muy concurrida, devota y estruendosa en casi todo el país. Sus devotos generalmente llevan el escapulario del Carmen como símbolo protector y con motivos piadosos. Una de las motivaciones que inspira esta devoción popular se relaciona con una especie de promesa de que quien lleve devotamente el escapulario de la Virgen estará bien protegido contra los peligros físicos y espirituales y tendrá una debida asistencia espiritual a la hora de la muerte. La Virgen ejerce una cierta omnipresencia protectora sobre sus devotos y se la considera como especial abogada de los moribundos, ya que se cree que quienes mueran con el escapulario se verán libres de las penas del purgatorio ${ }^{6}$. en las fiestas y peregrinaciones marianas suelen venderse o distribuirse los escapularios de la Virgen junto con otros objetos devocionales. Son bastante conocidos los santuarios de el Carmen de Apicalá (Tolima) y Villa de Leiva (Boyacá) a donde concurren anualmente numerosos fieles y devotos peregrinos.

5 Cfr., Moliner (1974, pp. 345-445); Pacheco (1975, pp. 538-546).

6 La iconografía de la Virgen del Carmen suele expresar esta creencia al presentarla en actitud de ofrecer el escapulario a los que sufren los tormentos de las llamas, como instrumento de rescate para las almas que purgan por sus pecados. 
La expresión ¡Virgen del Carmen! suele ser una exclamación espontánea y frecuente entre el pueblo como reacción ante algo inesperado o amenazante e indica el énfasis en el carácter protector de la Virgen. el nombre Carmen suele también ser bastante frecuente como nombre de personas e instituciones. es una devoción de gran arraigo entre los hombres y aún se celebra su fiesta anual con mucha solemnidad.

La advocación de la Virgen del Rosario ha tenido una constante difusión popular a través de toda la geografía e historia colombiana, unida a la práctica del rezo del rosario y la actividad de las cofradías que han llevado su nombre. el empleo del rosario como medio pedagógico de evangelización popular ha sido uno de los elementos pastorales y devocionales característicos de esta advocación mariana, como ya se ha dicho. Los frailes dominicos y las religiosas de la Familia Dominicana han tenido un papel preponderante en la historia de esta advocación; y el santuario de Nuestra Señora del Rosario de Chiquinquirá (Boyacá) ha sido uno de los principales centros de difusión para toda Colombia y países vecinos, así como los templos dedicados a la Virgen con este mismo nombre en Bogotá y en La estrella (Antioquia) y en al- gunas parroquias que llevan este nombre mariano. el Colegio Mayor del Ro- sario, fundado en Santafé de Bogotá por el dominico Fray Cristóbal de Torres en 1652, tuvo originalmente una motivación devocional ya que sus constituciones establecían el rezo diario del rosario como una de las obligaciones de profesores y estudiantes. Por su parte, los frailes dominicos fundaron instituciones en torno a los conventos y las cofradías del rosario, las cuales tuvieron sus buenas épocas como factores influyentes en la devoción mariana.

Las misiones populares (urbanas y rurales) generalmente motivan y promueven esta devoción como sucedió desde 1982 cuando se impulsó una misión popular por todo el país, parroquia por parroquia, en torno al rezo del rosario en familia (según el método y estilo del P. Peyton), como preparación pastoral para la celebración del cuarto centenario de la renovación de la imagen de la Virgen del Rosario de Chiquinquirá que se cumplió el 26 de diciembre de 1986 con la visita del papa Juan Pablo II. Así se trató de reactivar 
el interés del pueblo creyente por esta piadosa práctica devocional con un sentido familiar y misionero ${ }^{7}$.

Muchas imágenes de la Virgen veneradas en Colombia, aunque no hagan expresa relación al rosario, generalmente llevan este símbolo como elemento decorativo y devocional. También hay que anotar que el nombre Rosario es frecuente para designar instituciones religiosas, educativas y benéficas, así como para las personas. Hay también varios pueblos colombianos que llevan este nombre, así como unas hermosas islas en el Caribe, cerca de Cartagena. Se puede afirmar que esta advocación mariana tiene en Colombia una dimensión universal y que el rosario (camándula) es uno de los objetos religiosos de uso devocional masivo.

Otras advocaciones marianas frecuentes e importantes entre el pueblo colombiano son: La Candelaria, la Virgen de los Dolores, de la Salud, del Milagro, de los Remedios, de las Mercedes, de la Pobreza, del Refugio, del Perpetuo Socorro, del Amparo, del Buen Consejo, de las Misericordias, de Loreto, Maria Auxiliadora, la Virgen de Guadalupe, de Fátima, de Lourdes, la Medalla Milagrosa, Nuestra Señora de la Peña y la Macarena, además de las titulares de santuarios, parroquias, comunidades e instituciones ${ }^{8}$.

en la práctica religiosa popular las advocaciones de la Virgen se multiplican, se superponen o van paralelas y a veces con cierta discriminación y competencia unas con otras, según el poder taumatúrgico que se les atribuya. en ciertas épocas, algunas de estas advocaciones han alcanzado un mayor auge popular según diversas circunstancias y tendencias pastorales, pero generalmente los creyentes tienen especial devoción a la Virgen bajo alguna advocación particular, veneran sus imágenes, llevan sus símbolos,

7 Esta misión mariana nacional estuvo dirigida por los sacerdotes dominicos Luis Armijos y Luis Francisco Téllez.

8 Cfr., Llano Ruiz (1982, pp. $44-45$ y 107-110). Como lo indican los nombres de las advocaciones marianas, en gran parte hacen referencia a los beneficios que se esperan de la Virgen y a las necesidades que se le encomiendan en la oración; otras hacen referencia directa al lugar o santuario de origen o a privilegios o prerrogativas de índole dogmática. Como un rasgo devocional significativo, hay que tener en cuenta también que algunas ciudades como Medellín, Santa Marta y el Socorro llevan en sus escudos la imagen de María, bajo distinta advocación. A la Virgen se le llama a veces "Mamá linda", "Nuestra Señorita de Chiquinquirá", etc., y con otras expresiones semejantes que expresan ternura, sencillez e ingenuidad. 
practican sus devociones, celebran y participan en sus fiestas y expresan una gran confianza en su protección.

Las fiestas marianas en torno a las distintas advocaciones de la Virgen tienen también su puesto y significación especial como expresión pública de la religiosidad y la proyección social de la devoción particular'. En las fiestas marianas de tipo popular se encuentran y se autoidentifican los devotos de la Virgen, cumplen sus promesas y mandas, expresan en la oración sus necesidades, practican sus ejercicios de piedad, ofrecen sus donativos y limosnas, manifiestan su alegría y su acción de gracias al sentirse protegidos y ayudados por la Madre de Dios. Las fiestas marianas suelen ser de gran esplendor y devoción y se convierten en una fuente de contento y satisfacción para fieles y pastores.

Las fiestas marianas en las que el pueblo participa de una manera entusiasta, masiva y piadosa en Colombia son la de la Virgen del Carmen, de la Inmaculada Concepción y la del Rosario, así como la titular de cada lugar, santuario, congregación o institución. En muchos casos la fiesta está precedida de la novena correspondiente o de un triduo con predicación y otras actividades pastorales y devocionales. En torno a las fiestas marianas hay elementos festivos que adquieren una mayor presencia, funcionalidad y espectacularidad como el repique de las campanas, el uso de la pólvora, la música, las flores y decoraciones, así como algunos signos de ostentación económica. Sin embargo, las características de las fiestas marianas son muy variables en cada región y época. Hay tiempos y lugares en los que las fiestas marianas han caído en el olvido, la decadencia y la rutina o no han alcanzado ningún relieve; en otros casos están unidas a diversas manifestaciones folclóricas y culturales.

en algunas épocas y lugares de Colombia la dimensión festiva de la devoción mariana ha alcanzado una mayor proyección en el calendario religioso con la dedicación particular de los meses de mayo y octubre en honor de la Virgen Maria, en torno a la Virgen de Fátima (13 de mayo) y la del Rosario

9 Aquí nos referimos a algunos aspectos descriptivos de las fiestas marianas en concreto. Es significativo que a la Virgen del Rosario de Chiquinquirá se le celebran dos fiestas anuales, una en el aniversario de la Renovación ( 26 de diciembre) y otra en el de la Coronación (9 de julio), ambas generalmente con gran solemnidad y participación popular, como fiestas principales del calendario mariano colombiano. 
(7 de octubre). el tiempo festivo en honor de la Virgen se ha proyectado también a lo largo del año con la especial dedicación del sábado a honrar a la Madre del Señor. Se puede afirmar con certeza que en la celebración festiva en honor de la Virgen María es quizá donde la liturgia oficial de la Iglesia se ha encontrado más frecuentemente con la religiosidad popular, también es donde ambas fenomenologías y expresiones religiosas han convivido con cierta armonía y complementación.

\section{Las imágenes y santuarios marianos}

Las imágenes y santuarios marianos mediatizan y expresan en forma especial y artística la devoción mariana según las diferentes advocaciones ${ }^{10}$.

Así como cada persona o grupo de creyentes centra su devoción mariana en torno a alguna advocación particular, también tiene sus propias imágenes y orienta su devoción hacia algún santuario mariano, aunque no de manera exclusiva, localista o sectaria. en el uso simbólico de los objetos religiosos se establecen ciertas jerarquías y preferencias devocionales según distintos criterios de atracción, eficacia, creencias, motivaciones, etc. Tanto en los hogares como en los templos el creyente expresa su devoción a la Virgen simbólicamente con gestos y acciones, venerando las imágenes, rezando ante ellas, adornándolas con flores, encomendándoles sus necesidades y agradeciéndoles sus favores. A veces la relación con las imágenes es cuasi-interpersonal, dialogal y contractual, ya que los devotos les atribuyen

10 en otros contextos nos hemos referido al santuario como espacio de la práctica religiosa popular y a algunos de sus aspectos funcionales y simbólicos, cuyas ideas no vamos a explicitar aquí. Por otra parte, es importante considerar, aunque no ahora, específicamente el papel mediador de las imágenes en el catolicismo popular. Para una reseña de algunas imágenes de María en Bogotá y en la diócesis de Pasto, por ejemplo, cfr., Mesanza (1950, pp. 382-390 y $415-$ 416). Como factores devocionales marianos en torno a sus imágenes hay que tener en cuenta las ceremonias de coronación y las condecoraciones, así como las salidas ocasionales de las imágenes marianas desde sus santuarios hacia otras regiones, que son verdaderas peregrinaciones de la misma imagen con retorno triunfal a su lugar de origen: "Desde tu santuario, a nosotros ven", canta el himno a la Virgen del Rosario de Chiquinquirá. Hace unas décadas fue condecorada por el Gobierno nacional, con la "Orden de Boyacá", en el Grado de Gran Cruz, la Virgen de Nuestra Señora de Chiquinquirá, cuya imagen se venera en La estrella, Antioquia, cfr., Diario Oficial (1985); El Espectador (1985). 
a algunas de ellas no solo un "misterioso poder", sino también una especial capacidad comunicativa, una resonancia y afinidad con sus sentimientos y necesidades, lo cual es difícil discernir y valorar. Hay que decir también que la imaginería mariana es abundante y en algunos casos mayor que la cristológica y, por supuesto, más variada que esta, lo cual no deja de ser significativo para entender la relación entre la devoción a la Virgen y el sentido cristológico de la piedad popular, así como su eficacia mediadora.

Los santuarios marianos son especialmente concurridos, lo mismo que la celebración de la fiesta titular de cada uno de ellos. Allí acuden en romería sus devotos en distintas épocas del año, pero más particularmente cuando se trata de pedir por una necesidad urgente o grave, de cumplir una promesa hecha a la Virgen, de participar en su fiesta por devoción o costumbre, o de acompañar una peregrinación tradicional u ocasional. Los motivos y ocasiones de peregrinar al santuario mariano son diversos y el atractivo que ejerce cada santuario sobre los fieles es muy variable y sometido a distintas contingencias.

Ahora no nos vamos a referir explícitamente a los santuarios marianos importantes que han sido como núcleos de la piedad mariana desde los primeros tiempos de la cristianización de Colombia (Chiquinquirá y Las Lajas, ambos de la Virgen del Rosario); se pueden tener en cuenta las reseñas que se han hecho de algunos célebres santuarios marianos en Colombia ${ }^{11}$. Con ese telón de fondo debemos recordar ahora la fuerza convocante y aglutinadora del santuario mariano, así como su función en la conservación y difusión de la piedad popular y, sobre todo, su valor simbólico como ámbito de la experiencia religiosa, centro de confluencia peregrinante y lugar privilegiado de la evangelización. Lo que corresponde al simbolismo y función del templo como lugar de la experiencia religiosa popular y como lugar eclesiológico, se cumple de una manera especialmente vivencial, afectiva, humanizadora y evangelizadora al abrigo maternal del santuario mariano, que es como la matriz cultural del pueblo y de su identidad histórica. Varios son los aspectos simbólico-funcionales que sobresalen en los santuarios marianos, sobre todo si tienen un carácter nacional o regional. A algunos de estos aspectos

11 Cfr. Mesanza (1950); Mora Díaz (1945), como se cita en Ariza (1967, p. 84). 
nos vamos a referir en seguida, adelantando en cierta manera algunas consideraciones hermenéuticas sobre la devoción popular ${ }^{12}$.

el santuario mariano, generalmente unido a las raíces histórico-culturales de la religión popular, facilita el reencuentro del pueblo con su propia herencia religiosa y cultural, con sus valores autóctonos, con sus tradiciones y costumbres ancestrales y lugareñas fundamentales. en el santuario maria- no el pueblo recupera y realimenta su memoria evangélica original y tiene un lugar privilegiado para su expresión masiva, espontanea, sencilla, gene- rosa y libre, a la vez que intensamente vivencial. Lo religioso y lo materno se confunden y complementan con lo ancestral y cultural tanto en el plano individual como en el social en torno a la experiencia religiosa popular del santuario mariano.

Por cierta afinidad hogareña propia del santuario mariano, este se convierte para el pueblo en un espacio de libertad y encuentro que le ayuda a afianzar los valores de identidad patria y religioso-cultural; aquí despiertan y se acrecientan las motivaciones y sentimientos de preferencia a un pueblo creyente, la conciencia de hallarse formando parte de una comunidad que se dice Iglesia. el santuario es como el hogar universal de los creyentes, el centro geocultural interpretativo de la relación e integración como pueblo a la vez concreto y universal, geográficamente delimitado e históricamente móvil y peregrino.

el santuario mariano es un lugar de transformación y renovación evangélica de la cultura popular y de la experiencia histórica del pueblo, grupo o familia, y a la vez una instancia crítica de sus debilidades religioso-morales y de las desorientaciones práctico-doctrinales de su fe evangélica. el encuentro devocional con María es siempre un llamado hacia Cristo y hacia el Evangelio; la figura de María es un camino hacia el misterio de Cristo y un modelo de cómo ser conformes al evangelio. De alguna manera el pueblo presiente, vive y expresa estas profundas conexiones cristológico-marianas cuando habla de la Virgen como la Madre de Dios y de los hombres, la mujer

12 en algunas cuestiones seguiremos muy de cerca las conclusiones de los dos primeros Encuentros de Rectores de Santuarios del Cono Sur (1980-1981, respectivamente), publicadas en la Revista Medellín (1980 y 1981), ya que en los siguientes encuentros suelen replicarse dichas conclusiones sin mayores novedades teológico-pastorales. 
más santa, la pura y limpia, la más bella, la madre protectora, virgen bendita, intercesora, milagrosa y a la vez modelo de vida ${ }^{13}$.

en el santuario mariano se hace vivo y esperanzado el anhelo creciente de liberación integral que hay en el pueblo creyente, a través de los signos que expresan necesidades, frustraciones, expectativas, buenos deseos y propósitos y, esencialmente, en los signos de conversión del corazón por lo que implica de exigencias de cambio de mentalidad, valores, actitudes y aspiraciones. Allí concurren con esas expectativas los pecadores, marginados, analfabetos, enfermos, inconstantes, cansados, agobiados, desarraigados y todos los que sufren, porque perciben secretamente que los santuarios marianos son como los brazos misericordiosos de la Iglesia madre que los acoge, consuela, reconcilia, fortalece y anima en sus luchas. Los que regresan de una peregrinación mariana no solo llevan el sentimiento de satisfacción por una promesa y un deber cumplido, sino que también la esperanza de que la vida puede ser mejor y la liberación posible.

el santuario mariano también cumple una función servidora de la unidad eclesial ya que en la peregrinación se reinicia, sostiene, estimula y expresa de alguna manera la comunión de la unidad en la multiplicidad, en el agrupamiento desde la dispersión, en el reencuentro de los que viven distanciados (espacial y experiencialmente) de la Iglesia. Los que peregrinan juntos se manifiestan socialmente como signo global de una Iglesia que vive en la diversidad y la dispersión al modo de una familia multitudinaria de creyentes.

en medio de la transición creciente del pueblo hacia las formas culturales urbano-industriales con sus efectos desestabilizadores de la identidad cultural,

es de un valor incalculable que los santuarios se constituyan en aquellos lugares propicios donde el pueblo se siente identificado con su ser nacional o regional y donde percibe su vocación eclesial de Pueblo de Dios peregrino. en sus ámbitos las multitudes no son masa del orden natural sino de la fe. Como Iglesia encuentra allí a pastores, entran en contacto con una institucionalidad que los personaliza, y se reconocen

13 La experiencia religiosa popular sobre María se resume en torno a estas expresiones y otras parecidas, cfr., zuluaga (1977, pp. 43-46). 
en los santos, que son los testigos en los cuales se manifiesta el sentido de la existencia (Primer... n. 11) ${ }^{14}$.

Desde el punto de vista pastoral (en el que no nos corresponde entrar directamente ahora), bástenos con suscribir tres aspectos señalados por los participantes en el Segundo Encuentro de Rectores de Santuarios del Cono Sur (1981, 18-21 de may.) y que consideramos especialmente significativos y fecundos en el caso de los santuarios marianos. Los santuarios se presentan, desde estas perspectivas, como una riqueza para la Iglesia y uno de los lugares privilegiados para el ejercicio de su tarea evangelizadora, así como para la manifestación y celebración de la fe, de la justicia y de la misericordia ${ }^{15}$.

Finalmente, hay que decir que el pueblo creyente necesita de los santuarios marianos no solo para satisfacer ciertas necesidades religiosas dentro de un ámbito geocultural y sociohistórico peculiar, sino especialmente, y desde lo más íntimo de sus sentimientos religiosos, para encontrarse con esa "presencia sacramental de los rasgos maternales de Dios" (Puebla, 1979, p. 291).

\section{Las prácticas populares de piedad mariana}

Las prácticas populares de piedad mariana en su diversidad y simbolismo expresan de manera concreta la relación devocional del pueblo con la Virgen. Ya hemos hecho alusión a las fiestas, peregrinaciones y uso de objetos e imágenes como mediaciones importantes de la devoción mariana popular. Debemos señalar ahora más explícitamente que la práctica del rezo del rosario constituye uno de los elementos de mayor valor y significado para la piedad popular. Ha sido una de las prácticas devocionales verdaderamente arraigadas tanto en los hogares como en los templos y en el ámbito de la piedad individual, aunque su historia conoce tiempos de decaimiento y olvido.

en muchas familias, especialmente de ambiente campesino patriarcal, el rosario ha sido durante generaciones la oración de la mañana y de la

14 Cfr., Primer... (nn. 12-17).

15 Cfr., Primer... (n. 13). También, cfr., Galilea (1968); Galilea y González (1973, pp. 1-16, 232, 282, 449, 463). Gracia (1971). 
tarde; en las parroquias el rosario vespertino constituía una práctica ordinaria y concurrida cuando la misa se celebraba solamente por la mañana; en muchos casos el rezo del rosario acompañaba hace algunas décadas la misma celebración eucarística, como lo reconoce con pesar la exhortación Marialis Cultus (48); también durante las procesiones de las fiestas, las visitas a las funerarias y al cementerio, algunos novenarios y en otras ocasiones se acostumbra a rezar el rosario; esta práctica ha sido especialmente estimulada por los pastores durante los meses de mayo y octubre, dedicados a honrar a la Madre del Señor.

entre las diversas formas de rezar el rosario ha tenido bastante auge en ciertas épocas y lugares el llamado rosario de aurora.

Además de ser una forma de oración popular muy fácil para cualquier clase de personas, se constituía muchas veces en una manera de exteriorizar el fervor cristiano, el amor a la Virgen y la pertenencia a la Iglesia. Los peregrinos de los santuarios, los participantes en misiones populares y novenarios en honor de la Virgen suelen ser asiduos practicantes de esta devoción que generalmente hace un empleo abundante del canto popular, consignas, aclamaciones, vivas, etc., que estimulan y llenan de entusiasmo a sus devotos seguidores. Generalmente, es una oración muy dinámica y fervorosa.

el rosario ha sido en muchos casos la principal forma de oración de los cristianos, y a veces la única, en regiones en donde la presencia y la acción pastoral de la Iglesia ha sido ocasional o mínima durante largos periodos. el rosario ha sido la liturgia y el evangelio del pueblo pobre en regiones marginadas, convirtiéndose así en signo de comunión y eclesialidad importante y en una verdadera lectio divina de los pobres.

en torno al rosario, a su rezo y propagación, han girado muchas misiones de evangelización popular, cofradías y asociaciones, así como congregaciones religiosas, que han hallado en esta oración el núcleo evangélico de su espiritualidad y de su proyecto cristiano ${ }^{16}$.

16 en Colombia existe actualmente la Congregación de Dominicas del Rosario Perpetuo, fundada en Bogotá el 31 de mayo de 1953 por el P. Domingo María Méndez (gran predicador popular y devoto promotor del rosario) y la M. Cecilia Arciniegas. Tiene aprobación eclesiástica diocesana desde el 25 de mayo de 1982. También, aunque de origen cubano, están las hermanas Dominicas de Nuestra Señora del Rosario. 
La bibliografía sobre el rosario es relativamente abundante entre los dominicos, aunque generalmente son escritos de tipo piadoso, pastoral y poético ${ }^{17}$. el arte tiene una expresión cumbre, y quizá única en el mundo, en la Capilla del Rosario que forma parte del templo de Santo Domingo (Tunja) restaurado hace algunas décadas. Básicamente, está compuesta por hermosas pinturas de los quince misterios del rosario y es una catequesis permanente sobre el culto mariano. También en el campo artístico hay que señalar la producción cinematográfica de excelente calidad que se utilizó en la promoción del rosario en familia por casi todo el país, a la cual nos referimos más atrás ${ }^{18}$. Debemos tener en cuenta que los últimos pontífices han sido fervorosos promotores del rosario y que en la Exhortación Marialis Cultus el papa Pablo VI compuso nuevas orientaciones a la Iglesia para acomodar esta práctica de piedad a la renovación litúrgica y reorientar evangélica y pastoralmente la oración mariana. el papa Juan Pablo II añadió la nueva serie de misterios luminosos a esta forma popular de oración ${ }^{19}$.

en cierta convergencia y complementariedad con el rezo del rosario, y en el campo de las prácticas de piedad mariana, hay que mencionar otras formas de oración y piedad que han tenido o conservan aún vigencia e interés para el pueblo creyente. en este sentido debemos señalar el rezo del Avemaría, la salve, las letanías, el ángelus, la plegaria "Bendita sea tu pureza", y la que comienza "Acordaos, oh piadosísima Virgen María"; en algunos casos el Magníficat y ciertas invocaciones de carácter litánico o a modo de jaculatorias que han formado parte de la expresión orante de índole mariana. Se deben tener en cuenta también ciertos cantos marianos populares empleados principalmente en las procesiones y rosarios de aurora, como el que empieza "Madre mía, que estás en los cielos", y algunos himnos propios de las distintas advocaciones marianas.

17 Cfr., Ariza (1967).

18 Véase la nota al pie 9 y su contexto.

19 La exhortación Marialis Cultus trata lo referente al rosario en los números 46-55. La Sociedad Mariológica española realizó en su momento un extenso estudio sobre este documento, publicado bajo el título Culto y piedad mariana hoy (1978), digno de tenerse en cuenta. en las redes modernas de comunicación se encuentra amplia información sobre estos temas y prácticas. 
en el pueblo colombiano hay también algunas expresiones que, a modo de jaculatorias o exclamaciones espontáneas, se hallan frecuentemente vinculadas a la conversación ordinaria, como, por ejemplo, el decir "Ave María purísima", "eh, avemaría, pues", "Virgen del Carmen", "Ay, Virgen", "Virgen bendita", etc. Esto nos manifiesta que son múltiples y a veces sorprendentes las formas con las que se expresan los sentimientos de piedad mariana en el pueblo, aunque no siempre representan una lúcida conciencia de su significado y alcance.

\section{Otros elementos que configuran y manifiestan la piedad mariana popular}

Otros elementos que configuran y manifiestan la piedad mariana popular en Colombia son las asociaciones y movimientos marianos que han evolucionado desde las antiguas cofradías de origen español andaluz ${ }^{20}$, pasando por las Hijas de María, la Legión de María, la Esclavitud mariana, hasta las recientes Congregaciones marianas, las Mariápolis, etc. Como ya se ha dicho, las cofradías del rosario, de las cuales quedan algunas nuestras, ordinariamente prosperaron en torno a los conventos dominicanos y, como otras organizaciones, han surgido y siguen apareciendo en torno a las distintas comunidades e instituciones religiosas, cuyo estudio sería interesante y de utilidad pastoral.

También debemos mencionar en este apartado el uso de reliquias y $o b$ jetos relacionados con la devoción mariana, como son las estampas, escapularios, medallas, camándulas, objetos "retocados" en las imágenes de los santuarios marianos, el agua bendita llevada de estos santuarios, cirios y otros objetos guardados en los hogares como piadosos recordatorios de las peregrinaciones o de las fiestas marianas. Aunque son objetos con una función recordatoria y motivacional de la piedad, son a veces usados a modo de talismanes o fetiches a los que se les atribuye cierto poder protector de

20 Cfr., el apartado "Semana Santa" en Aldea Vaquero, Marín Martínez y Vives Gatell (1972-1975 IV, pp. 2404-2418); Moreno (1985); Bermejo y Carballo (1977). 
carácter mágico y supersticioso. en estos campos es muy difícil descubrir o señalar los límites y las desviaciones de la práctica religiosa popular.

Otros elementos devocionales marianos importantes son los relacionados con la presencia de la Virgen en torno a la celebración popular de la Semana Santa y la Navidad. en estos casos se percibe más fácilmente su referencia al misterio de Cristo, como enseña la Iglesia que debe orientarse a la piedad mariana ${ }^{21}$.

Por lo que llevamos dicho, queda manifiesto que la piedad mariana popular se desenvuelve dentro de una fenomenología muy compleja y a veces sutil, y que algunos de sus aspectos no carecen de ambigüedad y distorsión. en este ámbito entran en juego el espacio y el tiempo, las personas y sus acciones, motivaciones y situaciones, necesidades e intereses, intuiciones y actitudes, tradiciones populares y acciones pastorales, normas litúrgicas y costumbres piadosas, objetos de diverso valor simbólico y expresiones verbales peculiares, etc. La expresión religiosa propiamente mariana alcanza casi todos los ámbitos de la experiencia religiosa humana individual y colectiva; su significación es compleja y su tratamiento pastoral exige una especial capacidad de discernimiento, comprensión y crítica desde el evangelio. en orden a su comprensión y valoración, propondremos en seguida algunas pautas para su interpretación teológica, sin olvidar los cambios provocados por los fenómenos sociales, culturales y eclesiales que hacen que en cada época sea distinta la manera de venerar a Aquella que "llamarán bienaventurada todas las generaciones" (Lc 1,48). es lo que nos recuerda Pablo VI en la introducción de la exhortación Marialis Cultus con las siguientes palabras:

Ciertas prácticas culturales que en un tiempo no lejano parecían apropiadas para expresar el sentimiento religioso de los individuos y de las comunidades cristianas, parecen hoy insuficientes o inadecuadas porque están vinculadas a esquemas socioculturales del pasado, mientras que en distintas partes se van buscando nuevas formas expresivas de la inmutable relación de la creatura con su Creador, de los hijos con su Padre. esto puede producir en algunos una momentánea desorientación; pero todo aquel que con la confianza puesta en Dios reflexione

21 Cfr., MC. 25-28. 
sobre estos fenómenos, descubrirá que muchas tendencias de la piedad contemporánea - por ejemplo, la interiorización del sentimiento religioso - están llamadas a contribuir al desarrollo de la piedad cristiana en general y de la piedad a la Virgen en particular (17).

\section{Elementos teológicos para una interpretación de la devoción mariana popular}

Hemos visto que la piedad mariana es un elemento nuclear y envolvente del catolicismo popular colombiano y que presenta una fenomenología compleja, rica, variada y cambiante. Debemos ahora acercarnos a los principales aspectos teológicos implicados o expresados en este campo particular de la experiencia religiosa popular y proponer algunas claves para su interpretación y discernimiento. No pretendemos, por supuesto, tratar sobre las líneas fundamentales de la mariología en general, sino de los aspectos propiamente relativos al culto y a la devoción mariana, aunque suponiendo y teniendo en cuenta el contexto teológico general dentro del cual se inscribe esta parcela de la amplia y compleja temática teológica ${ }^{22}$.

\section{La función modélico-mediadora de María en la piedad popular}

La relación devocional del pueblo con María se expresa básicamente den- tro de la doble funcionalidad simbólica modélico-mediadora que se le atribuye, como consta por el análisis fenomenológico anterior y como lo hemos propuesto en el enunciado de la presente exposición. A estos dos conceptos (modelo y mediación) se puede reducir lo que el pueblo creyente ve, experimenta y busca en María a través de su práctica devocional; ambos conceptos, a su

22 Las orientaciones fundamentales más cercanas las tomamos del Concilio Vaticano II y de otros documentos del Magisterio eclesiástico. Cfr., LG, 52-69; SC, 13,103; la exhortación Marialis Cultus y algunos aspectos desarrollados pastoralmente en Puebla (1979, pp. 282-303, 844, 745, 454); en Santo Domingo (1992, pp. 53, 104 y 142); en Aparecida (2007, pp. 266-272). 
vez, reflejan, en ámbitos diferentes y complementarios, la misión maternal de María que en vez de oscurecer o disminuir el poder y significado de la mediación única de Cristo, la esclarece y manifiesta (LG, 60). En su maternidad divina está la raíz de su función mediadora (62) y la significación como "modelo de virtudes para toda la comunidad de los elegidos" (65) de Aquella que "sobresale entre los humildes y pobres del señor, que confiadamente esperan y reciben de Él la Salvación" (57). Todos los sentimientos, las motivaciones, los anhelos, las convicciones y creencias del pueblo en torno a la figura de María se mediatizan a través del modelo que encuentra en Ella y en la capacidad y eficacia mediadora que experimenta o le atribuye; aunque, ciertamente, en el campo devocional tiene mayor relieve la mediación intercesora que la ejemplaridad. Por otra parte, no parece seguro que la principal razón fenomenológica de la especial predilección del pueblo hacia la Virgen como mediadora en el catolicismo popular sea la presunta lejanía y desinterés que tiene Dios en la sensibilidad y experiencia religiosa del pueblo, como suelen afirmar los fenomenólogos e historiadores de la religión ${ }^{23}$. Parece más bien que la mediación de María como experiencia fenomenológica en el ámbito devocional es la forma peculiar con que el pueblo, según su propia sensibilidad y reales posibilidades espirituales, trata de apropiarse del poder y de la misericordia de Dios, es decir, de comunicarse eficazmente con su trascendencia e inmanencia, como parece sugerirlo la expresión consagrada en el documento Puebla que habla de María como "la presencia sacramental de los rasgos maternales de Dios" (1979, p. 291). No se trata quizá de que sea más cercana a Dios sino más semejante a los hombres, en cuanto se le descubre como mujer del pueblo, María de Nazareth, a la vez que llena de gracia y Madre del Señor. en su primera condición resplandece su ejemplaridad como algo histórico y cultural mientras que en la segunda se expresa y posibilita su función mediadora.

23 Quiero decir que la figura literaria del Deus otiosus ha de ser relativizada críticamente, ya que se ha llegado a convertir en un tópico utilizado indiscriminadamente por estudiosos del fenómeno religioso con peligro de caer en simplificación y trivialización de experiencias religiosas más ricas y complejas. 


\section{Necesidades, sentimientos y motivaciones en la piedad mariana}

A este propósito debemos hacernos varias preguntas: ¿qué es lo que busca el pueblo a través de su práctica devocional mariana? ¿qué sentimientos y motivaciones expresa en sus formas de piedad hacia la Virgen? Aunque ya en parte se han respondido algunos aspectos de estos planteamientos, debemos explicitar un poco más su contenido y sus razones teológicas.

en contra de una tendencia generalizadora y simplista, hay que reconocer que no todas las expresiones devocionales son siempre, consciente y directamente, motivadas por intereses inmediatos (de tipo utilitarista y mágico), ni referidos a necesidades concretas de orden ocasional o coyuntural y material. en la piedad mariana popular muchas veces resplandece la gratitud sencilla y confiada del amor de un pueblo creyente que aprendió a querer a la Virgen y encuentra connatural a su sensibilidad religiosa la devoción mariana. en María el pueblo se siente plenamente comprendido e interpretado porque ella, en su carisma femenino y en su función maternal, se interesa por todo lo vital y humano.

Como el pueblo confía en el amor maternal de María y lo interpreta con la categoría de poder intercesor ante Dios de una manera casi espontánea y connatural, por eso acude a ella más fácilmente y le confía sus preocupaciones, necesidades y angustias. Podría decirse que lo que aparece externamente con más volumen es la búsqueda de solución a ciertas necesidades o situaciones difíciles de distinta índole, pero en esa búsqueda subyace una confianza fundada en el campo de la relación con Dios (más intensamente que el interés utilitarista), es decir, en el ámbito de la fe. Porque confía en la eficacia de esa relación, el pueblo creyente busca en María ciertos favores y milagros, espera ayuda y protección, consuelo, guía y fortaleza ante los problemas de salud y pobreza, ante las difíciles condiciones familiares, morales y laborales, ante las situaciones de limitación, angustia, peligros e incertidumbres de una vida llena de sufrimientos ${ }^{24}$. Si la piedad mariana fuera sim-

24 Todas estas expectativas del pueblo creyente ante María se expresan de forma inigualable en la plegaria de la Salve y en el himno litúrgico Ave Marís Stella, cuyo eje en ambos casos parece ser la súplica, "Monstra te esse matrem...". Igualmente el canto mariano tan 
plemente utilitarista no sería perseverante, si buscara solamente la eficacia del poder divino no tendría esa continuidad histórica que la caracteriza, ni esta incomprensible persistencia más allá del fracaso de la esperanza y de la sensación que a veces tiene de no ser escuchado.

Los devotos de la Virgen también buscan a través de ella a Dios, aunque no siempre de forma consciente, y desean para sí y para otros una vida de conversión según Dios y la salvación. La oración por la conversión de los pecadores es rasgo característico de la piedad mariana y se halla unida especialmente a algunas advocaciones, como en el caso de la Virgen de Fátima, por ejemplo. Muchas promesas hechas a la Virgen tienen motivaciones morales y espirituales profundas que no podemos demeritar ni olvidar. Los actos devocionales marianos (o ejercicios de piedad a la Virgen) ${ }^{25}$, en general, expresan sentimientos de amor filial y reconocimiento agradecido y alabanza, aunque, ciertamente, con una carga, a veces exagerada, de emotividad, sentimentalismo inmediatista y pasajero. A la Virgen se le pide el amparo y la bendición, la gracia y la misericordia, la ayuda para llegar a Dios y llevar una vida cristiana digna y ejemplar. el pueblo sabe que ella es la Madre de Dios, de Cristo y nuestra; que como tal es intercesora valiosísima, a la vez cercana a Dios y a los hombres, maternal y protectora en toda ocasión. Hay gente que dice que la Virgen no les falla. Por eso se la invoca confiadamente con los títulos de Abogada, Auxiliadora, Socorro, Mediadora (LG, 62), aunque no haya claridad conceptual sobre su puesto y función dentro del plan de Salvación y su peculiar relación con Cristo y la Iglesia.

Debemos recordar que en muchos casos la piedad mariana ha sido la única mediación persistente en "sectores que carecían de atención pastoral adecuada" (Puebla, 1979, p. 284), lo cual ha contribuido quizá al engrandecimiento simbólico de María y ha llevado inconscientemente a diluir la figura de Cristo, a relativizar el valor de los sacramentos y a considerar casi innecesaria la apelación directa a Dios. La figura de María, ciertamente, ha sufrido

arraigado en el pueblo cuya primera estrofa dice: "Madre mía que estás en los cielos, / envía consuelo a mi corazón. / Cuando triste llorando te llame, / tu mano derrame feliz bendición..." También muchos cantos marianos populares antiguos y recientes suelen expresar esta variedad de sentimientos y motivaciones en torno a las diversas situaciones de precariedad y sufrimiento. 25 Cfr., MC $(24,25,28,31)$. 
en algunos casos una especie de divinización en afinidad o continuidad con las deidades femeninas de los antepasados. Se ha llegado a vivir la piedad mariana dentro de un cierto confusionismo teológico y simbólico que hace difícil encontrar el lenguaje verbal adecuado para hablar comprensiblemente de Dios, de Jesucristo, del espíritu, de la Trinidad en relación con María. Por otra parte, la imaginería tampoco ha prestado gran ayuda en orden a expresar los dogmas teológicos en su relación orgánica y complementaria de una forma adecuada ${ }^{26}$, ni cierta literatura devocional (MC, 34), ni "algunas connotaciones de la imagen popular y literaria de María" (36). A este respecto suenan actuales las palabras de Pablo VI, al advertir que,

cuando la Iglesia considera la larga historia de la piedad mariana, se alegra comprobando la continuidad del hecho cultural, pero no se vincula a los esquemas representativos de las varias épocas culturales $\mathrm{ni}$ a las particulares concepciones antropológicas subyacentes, y comprende cómo algunas expresiones de culto, perfectamente válidas en sí mismas, son menos aptas para los hombres pertenecientes a épocas y civilizaciones distintas $(36)^{27}$.

Las diversas situaciones culturales, sociales y familiares no solo hacen variar la validez de las expresiones culturales y devocionales, sino también sus motivaciones, intereses, sentimientos y el horizonte teórico-práctico para su interpretación. Sin embargo, en cualquier caso y condición, las categorías hermenéuticas de ejemplaridad y mediación conservan su validez para la interpretación de la práctica devocional mariana, como ya se ha dicho.

26 este es uno de los aspectos que se trata en Grabar (1985).

27 esta observación se ha de tener presente a la hora de señalar aspectos diferenciales de la piedad mariana colombiana y en general latinoamericana en relación con la piedad mariana española, a fin de valorar debidamente su continuidad histórico-teológica y su diversidad sicológico-cultural. Colombia es profundamente mariana como españa, pero tiene rasgos diferentes. 


\section{La piedad mariana y la vida del pueblo creyente}

Para plantear el sentido de esta reflexión podemos preguntarnos ¿cómo relaciona el pueblo creyente la piedad mariana con su propia vida? Desde un punto de vista general y en el campo del ejercicio del culto, Pablo VI decía que María es "maestra de vida espiritual" y, desde una perspectiva histórica, agregó: "Bien pronto los fieles comenzaron a fijarse en María para, como ella, hacer de la propia vida un culto a Dios, y de su culto un compromiso de vida" (MC, 21). Sin embargo, hay que reconocer que en la vida concreta del pueblo ha prevalecido con mayor fuerza la ejemplaridad cultural de María (como mujer piadosa, devota, obediente) que la dimensión de su compromiso (como mujer profética, fiel servidora). Esto, en parte, debido a cierta tergiversación o utilización interesada de la devoción mariana, como lo plantea críticamente Gustavo Gutiérrez a propósito de un texto del Documento de Consulta, previo al documento de Puebla. en efecto, dice el autor:

Nadie ignora las tergiversaciones de las que ha sido objeto la devoción a María, ni la utilización que se ha hecho de ella para "espiritualizar" el mensaje cristiano hasta hacerlo inofensivo como un perrito falde- ro. Pero los pobres de América Latina redescubren en María a la hija de un pueblo sojuzgado, que sufre y espera. Por eso el Magníficat ha sido considerado desde el comienzo como un texto central en una espiritualidad de la liberación. ese texto que nos habla de la alegría que produce el amor gratuito del Padre, nos dice también que los poderosos serán derribados, los ricos se irán con las manos vacías y que Dios reivindica y levanta la mística y la historia, están allí expresadas con vigor inigualable. Sin vida contemplativa no hay vida cristiana, pero sin compromiso con los pobres y oprimidos tampoco. La dimensión liberadora del mensaje de María, que el pueblo intuía, aparece cada vez más clara (1979, pp. 166-167)

28 Cfr., Romabel (1980, pp 18-23 y 48-52). Hay que ver cómo en general la mujer colombiana ha introyectado en su propia experiencia cotidiana la imagen de María como mujer sufriente resignada, más que otros aspectos, a través de la práctica religiosa y de la experiencia sociocultural, especialmente en el ámbito campesino y de los sectores pobres de las ciudades. Pero esa situación conformista va cediendo poco a poco también como obra de una nueva 
este "pueblo sojuzgado, que sufre y espera" ha aprendido tradicionalmente a venerar a la Virgen como Reina celestial, llena de prerrogativas o privilegios suprahumanos, más cercana a las históricas condiciones humanas. Desde esta perspectiva, su piedad mariana ha estado en cierta ruptura con las reales situaciones de su vida concreta. Pero a la vez la figura de la Virgen de la Navidad y de la Semana Santa ha ayudado un poco al acercamiento y sintonía entre María y el pueblo, además de la reflexión creyente y comunitaria sobre las implicaciones prácticas del cántico de la Virgen y del descubrimiento de su dimensión solidaria como mujer del pueblo. Desde estas perspectivas, la piedad mariana va dejando de ser un motivo e instrumento para una moralización o espiritualización simplista del mensaje cristiano sobre María y va adquiriendo una verdadera dimensión evangélica en su función modélico-mediadora, "como modelo de virtudes para toda la comunidad de elegidos" (LG, 65).

En continuidad con esta peculiar afinidad afectiva, devocional y existencial entre el pueblo y María, habría que situar algunos de los valores positivos que caracterizan la idiosincrasia y sicología popular que expresa el alma del pueblo colombiano. esto ayudaría a ver más claramente la relación entre la devoción mariana y la vida concreta del pueblo, en lo cual no podemos detenernos ahora. Por otra parte, se hace necesario conectar la reflexión teológica sobre María con la experiencia concreta de los creyentes, ya que muchas veces ni la praxis devocional mariana ha interesado a la reflexión, ni la reflexión ha repercutido sobre la praxis religiosa, y el pueblo muchas veces sigue aferrado contra viento y marea a su práctica devocional mariana aunque carezca de elementos de comprensión y reflexión teológica ${ }^{29}$.

el mensaje de María sigue siendo iluminador y estimulante para el hombre que busca esclarecer su propio misterio y realizar plenamente su vocación, como bien lo recuerda el papa Pablo VI:

Al hombre contemporáneo, frecuentemente atormentado entre la angustia y la esperanza, postrado por la sensación de su limitación y asaltado por aspiraciones sin confín, turbado en el ánimo y dividido en

manera de ver el evangelio y de plantearse la vida cristiana desde un sentido más profundo de la fe de los pobres. Cfr., Congregación (1986, 97-100).

29 en torno a estas inquietudes es interesante y esclarecedor el texto de Rubio (1984). 
el corazón, la mente suspendida por el enigma de la muerte, oprimido por la soledad mientras tiende hacia la comunión, presa de sentimientos de náusea y hastío, la Virgen, contemplada en su vicisitud evangélica y en la realidad ya conseguida en la Ciudad de Dios, ofrece una visión serena y una palabra tranquilizadora: la victoria de la esperanza sobre la angustia, de la comunión sobre la soledad, de la paz sobre la turbación, de la alegría y de la belleza sobre el tedio y la náusea, de las perspectivas eternas sobre las temporales, de la vida sobre la muerte $(\mathrm{MC}, 57)^{30}$.

\section{Aspectos cristológicos y eclesiales de la piedad mariana}

el núcleo teológico y la razón de ser de la dimensión cristológica y eclesiológica de la figura de María y de su culto es su condición de elegida por Dios para ser la madre de Cristo por la encarnación y madre de los creyentes en el orden de la gracia ${ }^{31}$. A este núcleo teológico hay que referir los dogmas, títulos y prerrogativas, así como la situación y función de María en el plan de Salvación. el reconocimiento de la vocación maternal de María explica a la vez "todo el influjo salvífico de la Santísima Virgen sobre los hombres" (LG, 60), basado en la mediación única de Cristo, y la ejemplaridad que María representa para el pueblo creyente por su estrecha unión con el señor.

estos fundamentos teológicos mínimos parecen expresarse a modo de intuiciones, o convicciones latentes, en la práctica devocional mariana popular, cuando ésta no se halla patológicamente caracterizada por "actitudes culturales erróneas" (MC, 38). esto se desprende de considerar que el pueblo invoca a la Virgen principalmente como protectora (en referencia al poder de Dios, a su trascendencia) y como intercesora (en relación con la misericordia divina, con su inmanencia). en ambos casos se descubre su estrecha vinculación maternal humana y divina. esta doble manera de invocar a María es, además, la clave fundamental para interpretar la piedad mariana popular en

30 Cfr., GS, 22.

31 Cfr., LG (52, 53 y 61). 
el ámbito de la cristología y en la eclesiología y para entender por qué se le considera la más cercana a Dios y también la más semejante al alma popular.

en efecto, los núcleos teológicos fundamentales dentro de los que hay que ubicar e interpretar la presencia, función y significación histórico-salvífica de la figura de María son el misterio de la Encarnación y la comunión de los $\operatorname{santos}^{32}$. La doble y complementaria función modélico-mediadora de María se realiza y fundamenta en el orden de su unión con Cristo (encarnación) y se expresa en el ámbito de la comunión de los santos desde su peculiar condición como miembro sobreeminente, tipo y figura de la Iglesia de Cristo ${ }^{33}$. En Ella el pueblo ve reflejada la obra salvífica de Dios en Cristo y vislumbra el horizonte final y perfecto de su condición creyente, como lo expresa la liturgia de la Asunción de la Virgen (15 de agosto).

María ciertamente está unida de modo indisoluble a Cristo en el misterio de la salvación y es reconocida como fruto excelso de la redención y como signo preclaro de lo que dentro de la Iglesia está llamada a $\operatorname{ser}^{34}$; pero también hay que referirla antropológicamente a su condición histórica como mujer creyente en un pueblo, en una época y en unas condiciones de vida determinadas ${ }^{35}$ (cf. LG, 8).

La peculiar sintonía espiritual devocional del pueblo con María cuenta con los fundamentos teológicos explicativos e interpretativos aducidos, pero estos, a su vez, se apoyan en las dimensiones y condiciones antropológicas de su vocación histórica, que es necesario tener en cuenta para no divinizar su figura ni desfigurar su culto. Esto nos ayudará a contrarrestar en el catolicismo popular las tendencias

a hacer de la Virgen una devoción en sí, desligada del Misterio de Cristo y de la Iglesia; a divinizar a María situándola del lado de Dios y no del lado de los redimidos: a hacer del catolicismo la religión de Jesús y de María más que la religión de Jesucristo (Galilea, 1968, p. 154) ${ }^{36}$.

32 Cfr., Laurentín (1984).Véase también la ponencia de Osuna (1984); Müller (1985).

33 Cfr., LG $(63,65)$.

34 Cfr., SC (103).

35 Cfr., LG (8).

36 Cfr., MC (25-28). 
Desde el punto de vista histórico del desarrollo de la piedad mariana, debemos tener en cuenta que debe entenderse en el contexto de una progresiva acentuación de la devoción a la humanidad de Cristo y de los aspectos que, de una manera más directa, afectan a la sensibilidad del pueblo. en este sentido se enfatizan, más desde la predicación popular que desde la teología, los aspectos más sensibles y emocionales que rodean el acontecimiento del nacimiento del Señor y el de la pasión redentora (Bernal, 1984, p. $292)^{37}$.

\section{María, la creyente mujer del pueblo}

Bajo este sencillo enunciado podemos acercarnos a la dimensión antropológica de María y comprender la peculiar semejanza de su condición histórico-cultural con la de nuestro pueblo. esta relación nos ayudará también a comprender la profunda sintonía religiosa y afectiva del pueblo creyente con la figura de María y los motivos antropológicos de su piedad mariana. en ella el pueblo adivina, descubre o proyecta su propia realidad humana y religiosa, sus experiencias, expectativas, necesidades y limitaciones.

María, según la imagen que nos presenta el Nuevo Testamento, pertenece a la estirpe de los pobres de yahvé que creen, oran, sufren y esperan; y en esto refleja lo que vive ordinariamente nuestro pueblo en su vida cotidiana. en el ámbito de su relación con Dios, ella escucha, acoge y obedece la Palabra divina con esa intensa simplicidad de los que no están llenos de prejuicios ni de vanidad. Busca la voluntad de Dios y la cumple en el acontecer ordinario de su condición femenina, declarándose como servidora y pobre ante el Señor. Pero, como bien lo advierte René Laurentín,

que María sea una mujer pobre, quizá iletrada, en un tiempo tan subdesarrollado, no significa mediocridad o indigencia, sino el colmo de la riqueza de los pobres, destinatarios del evangelio, pues los pobres de yavé, sin las deformaciones o esclavitudes inherentes al poder, tener y

37 Cfr., Müller (1985, pp. 81, 115-125). 
saber de este mundo, están más cerca de Dios, son más semejantes a Él que los que cuentan a los ojos del mundo $(1984, \text { p. } 51)^{38}$.

esta consideración es de gran interés y actualidad para la piedad popular porque en la semejanza entre la experiencia de María y la condición del pueblo se percibe que ella es una mujer pobre, como los pobres del pueblo y creyente como ellos, solidaria en su humanidad, en su fe y en sus precarias condiciones sociales y culturales, en su actitud ante la vida y ante Dios.

María, al reconocerse como la humilde sierva del Señor y hacerse obediente a sus planes, asume su propia vocación desde la condición limitada y pobre de mujer del pueblo, que solo en su fe y en su esperanza se sabe valedora ante Dios, expresando la radical disponibilidad que caracteriza a los que se dejan guiar por el espíritu. Como bien lo recuerda el documento de Puebla, "ella es la creyente en quien resplandece la fe como don, apertura, respuesta y fidelidad" (1979, p. 296). “En el Magníficat se nos manifiesta vacía de sí misma y poniendo toda su confianza en la misericordia del Padre" (p. 297), a la vez que como mujer profética anuncia que el Señor ha mirado su humillación, hace llegar su misericordia a sus fieles, y con la fuerza de su brazo dispersa a los soberbios, derriba a los poderosos, despide vacíos a los ricos, mientras que exalta a los humildes y sacia a los hambrientos, acordándose de su misericordia y cumpliendo su promesa ${ }^{39}$.

en un medio sociocultural donde la profanación y desprecio de la dignidad de la persona humana es constante y la situación de la mujer, precaria e injusta, es de gran valor profético comprender y declarar que en María

Dios dignificó a la mujer en dimensiones insospechadas. En María el evangelio penetró la feminidad, la redimió y exaltó. esto es de capital importancia para nuestro horizonte cultural, en el que la mujer debe ser valorada mucho más y donde sus tareas sociales se están definiendo más clara y ampliamente (Puebla, 1979, p. 299).

38 en esta perspectiva se inscriben bastantes escritos de origen y cuño latinoamericano sobre la Virgen María, cfr., Galilea (1976); Idigoras (1982); Boff (1979); Alliende (1978).

39 Cfr., Lc, 1,46-55; MC (37). 
La condición femenina y creyente de María es una dimensión que no solo no se puede olvidar ni menospreciar sino que se ha de profundizar más en orden a comprender cada vez mejor su condición solidaria con nuestro pueblo pobre y creyente que es en particular afecto a ella y profundamente devoto de su misterio. La piedad mariana popular podrá superar sus deficiencias en la medida en que la figura de María sea clara en su dimensión humana y en su vocación divina, en su condición de Madre y Virgen, en su función de mediadora y modelo, en inseparable vinculación con su divino Hijo y con los que creen en Él: Madre y hermana de los pobres. Al proceso de desdivinización y desmitologización de sus prerrogativas y privilegios debe corresponder una adecuada humanización de su figura y de su significación como mujer del pueblo para que desde el campo de la piedad popular resplandezca su dimensión profética y liberadora sobre el pueblo pobre que cree, ora, sufre y espera. Así, María, como la creyente mujer del pueblo, puede ser redescubierta como camino del pobre hacia Cristo liberador y no solo como objeto de veneración ni como un fetiche sentimental de la piedad popular. La adecuada valoración de la figura de María en este ámbito es condición y garantía del sentido cristiano de la piedad mariana y de su vigencia histórico-social" ${ }^{40}$; esto nos "llevará a descubrir cómo María puede ser tomada como espejo de las esperanzas de los hombres de nuestro tiempo" (MC, 37), y "pedagoga del evangelio en América Latina" (Puebla, 1979, p. 290).

\section{Sobre el sentido cristiano de la piedad mariana}

La exhortación Marialis Cultus está prácticamente dedicada a orientar la piedad mariana, sobre lo cual no nos vamos a extender. Solamente vamos a fijarnos en algunos peligros que se ciernen sobre la piedad mariana popular y en algunas condiciones o criterios que se han de tener en cuenta para garantizar su correcto sentido cristiano. el tratamiento de estos aspectos será muy sumario por razones de espacio y metodología ${ }^{41}$.

40 Cfr. MC (34).

41 Cfr. LG (66-69); SC (103, 111). Llano Ruiz (1982, pp. 115-133) ha propuesto algunas pautas pastorales para la orientación de las devociones marianas, dignas de tenerse en cuenta. 
Por el catecismo, la predicación y la práctica devocional, el pueblo ha conocido a la Virgen y ha aprendido a venerarla con especial devoción y afecto como Madre del Verbo encarnado, según se profesa en uno de los artículos del credo $^{42}$. De alguna manera, también al mismo pueblo se le ha explicado el sentido que tiene el culto a la Virgen y a los santos y su relación con el culto a Dios, de acuerdo con una larga tradición de la Iglesia.

El mismo Concilio Vaticano II, fiel a una venerable y rica tradición cristiana, amonesta a todos los hijos de la Iglesia para que fomenten con generosidad el culto a la Santísima Virgen, tanto en el ámbito litúrgico como en el de los ejercicios de piedad hacia ella y hacia sus imágenes ${ }^{43}$. Pero advierte igualmente sobre la necesidad de mantener un sano equilibrio evitando tanto la "indebida exageración" (maximalismo) como la "excesiva mezquindad" (minimalismo), y de buscar en las fuentes teológicas y litúrgicas los criterios de actuación y corrección, el primero de los cuales consiste en la orientación cristológica de la piedad mariana, ya que Cristo es el "origen de toda verdad, santidad y piedad" (LG, 67).

el Magisterio de la Iglesia ha mostrado la preocupación por evitar todo lo que pueda inducir a error en este campo, sobre todo frente a los "hermanos separados", aunque históricamente la piedad mariana haya sido precisamente una especie de arma frente a ellos.

en cuanto a los criterios que deben guiar a los creyentes, el mismo Concilio señala que

la verdadera devoción no consiste ni en un sentimentalismo estéril ni en una mera credulidad, sino que procede de la fe auténtica, que nos induce a reconocer la excelencia de la Madre de Dios, que nos impulsa a un amor filial hacia nuestra Madre y a la imitación de sus virtudes (LG, 67).

\footnotetext{
Aquí nos movemos más en el campo hermenéutico que en lo pastoral, conforme a la orientación general del presente estudio.

42 Cfr., Astete (1980, nn. 81-90). Para algunos aspectos histórico-litúrgicos de la piedad mariana, cfr., Bernal,(1984, p. 286-296).

43 Cfr., LG (66-67).
} 
Sin embargo, por diversos motivos, la piedad mariana no ha estado exenta de tentaciones, manipulaciones, desviaciones, incoherencias y excesos. Así lo hacía ver Pablo VI, cuando hablaba de dificultades, expresiones menos aptas, actitudes culturales erróneas y desviaciones que se deben corregir ${ }^{44}$.

De manera sumaria, siguiendo a Juan Martín Velasco, podemos señalar los principales peligros que corre la piedad mariana, en los siguientes términos:

Son conocidos los peligros que acechan al catolicismo devocional en general y particularmente a las devociones marianas. en ellas puede expresarse una poco sana búsqueda de seguridad; el sujeto de las devociones puede caer en la tentación de buscar a través de ellas su propio interés, sublimado a veces en términos de búsqueda de la salvación; a la práctica devocional le acecha el peligro de la rutinización, que separa los actos de las actitudes que debieran vivificarlos; no es raro que sirvan para fomentar un sentimentalismo ayuno de ideas y de compromiso; $y$, por último, tienen su peor peligro en la caída en actitudes fanáticas, que ponen las devociones sobre todo y excluyen del cristianismo a quienes no participan en ellas con el mismo entusiasmo (1984, p. 162).

La creciente recuperación que a veces se advierte en el campo de la piedad mariana no está exenta de nuevos o viejos riesgos, como pueden ser ambigüedad mágica de las actitudes; riesgo de caída en la superstición; búsqueda desenfrenada de lo maravilloso; sustitución de las tareas éticas y de los compromisos socio-políticos de la fe por una manifestación folclorizante de la misma; contaminación del cristianismo con una búsqueda de ganancias económicas que contradicen el espíritu de pobreza y pueden llevar a la acumulación de riquezas en contraste con la pobreza de los fieles que frecuentan esas fiestas, utilización política del sentimiento de identidad experimentado por las masas en torno a los santuarios (p. 164).

44 Cfr., MC (36-39). 
Ciertamente estos no son solamente peligros y tentaciones que amenazan la práctica religiosa popular y especialmente el campo de la devoción mariana. Son a veces una realidad concreta con la que luchan o conviven los esfuerzos de renovación pastoral. ¿qué criterios deben guiar la recta ordenación de la piedad mariana popular para que conserve su verdadero sentido cristiano? entresacamos algunas indicaciones del autor que acabamos de mencionar porque nos parecen esclarecedoras y válidas ${ }^{45}$.

Dada la condición temporal, espacial y corporal del hombre, hay que tener en cuenta la necesidad de encarnar sus actitudes interiores en actos externos, referidos a objetos y lugares precisos. es decir, hay que reconocer que las mediaciones devocionales son necesarias, múltiples y densas y deben reflejar la cultura, el sentimiento, las condiciones de vida de las comunidades y de las personas devotas, dejando a salvo la fidelidad fundamental a lo cristiano. No se puede pretender una desencarnación o falsa espiritualización de la piedad popular sacándola del ámbito de lo sensible, histórico y encarnacional, con el pretexto de purificación o evangelización.

La piedad mariana deberá reflejar los elementos esenciales de la vida cristia$n a$, es decir, las dimensiones teologal, cristológica, pneumatológica y eclesial que constituyen el núcleo conceptual referencial del ser cristiano. La validez de la piedad mariana depende de su coherencia global con el conjunto del hecho cristiano, de la adecuada sintonía con su esencia, con sus leyes estructurales, con su estilo y dinamismo.

La piedad mariana debe ser también expresión de la gozosa libertad de los hijos de Dios y no objeto de una obligación ni de un tradicionalismo rutinario o costumbrista. Debe ser expresión festiva de una gozosa vivencia de la fe cristiana que refleje la fe de Aquella a quien llaman bienaventurada todas las generaciones.

Finalmente, para garantizar que las prácticas de piedad mariana estén centradas en la verdadera adoración de Dios y el servicio de los hombres, teniendo como criterio a Jesucristo y su vida, es necesario buscar

45 Cfr., Martín Velazco (1984, pp. 162-166). Tomamos sus indicaciones casi literalmente aunque esquematizándolas un poco para su mejor comprensión. Aquí también pueden ser útiles las propuestas críticas en Salado (1980, pp. 323-372). 
que tales devociones estén en relación con los demás aspectos de la vida y no separadas de ellos. que colaboren en la transformación de la realidad y no sean éticamente y humanamente estériles. que colaboren en la salvación y liberación del hombre y no le sometan a nuevas esclavitudes. que sean posibles medios para hacer presente el único evangelio de la presencia salvadora de Dios en Jesucristo (Martín Velazco, 1984 , p. 166$)^{46}$.

La piedad mariana debe conservar su dimensión católica y su sentido misionero como nos lo recuerda la Constitución Lumen Gentium en la siguiente exhortación:

Ofrezcan todos los fieles súplicas apremiantes a la Madre de Dios y Madre de los hombre para que ella, que ayudó con sus oraciones a la Iglesia naciente, también ahora, ensalzada en el cielo por encima de todos los ángeles y bienaventurados, interceda en la comunión de todos los santos ante su Hijo hasta que todas las familia de los pueblos, tanto los que se honran con el título de cristianos como los que todavía desconocen a su Salvador, lleguen a reunirse felizmente, en paz y concordia, en un solo Pueblo de Dios, para gloria de la santísima e indivisible Trinidad (69).

\section{Referencias}

Aldea Vaquero, q., Marín Martínez, T. y Vives Gatell, J. (eds.). (1972-1975). Diccionario de historia eclesiástica de España. Madrid: CSIC, Instituto enrique Flórez.

Alliende, J. (1978). La cuestión mariana en América Latina. Aporte para un temario y algunas posturas. Revista Medellín, 4(15), 423-433.

Aparecida. Documento conclusivo. V Conferencia General del Episcopado latinoamericano y del Caribe. (2007). Bogotá: Conferencia episcopal de Colombia.

46 estos parecen ser los criterios fundamentales mínimos para garantizar el sentido cristiano de la piedad mariana popular; a ellos habría que referir las propuestas pastorales concretas para cada uno de los aspectos devocionales, como el rosario, las peregrinaciones, el uso de las imágenes y objetos, la celebración de las fiestas marianas, etc. 
Ariza, A. e. (1950). Hagiografía de la milagrosa imagen de Nuestra Señora del Rosario de Chiquinquirá. Bogotá: Iqueima.

Ariza, A. e. (1956). Nuestra Señora del Rosario de la Conquista, del Convento de Dominicos de Santafé de Bogotá. en Anales de la Provincia Dominicana. Bogotá: Editorial Cooperativa de Artes Gráficas.

Ariza, A. e. (1967). Bibliografía de la Provincia Dominicana de Colombia. Bogotá: Pax.

Astete, G. (1980). Catecismo de la doctrina cristiana. Pasto: Casa Mariana.

Bermejo y Carballo, J. (1977). Glorias religiosas de Sevilla. Sevilla: Diputación de actos formativos Hermandad Jesús Despojado.

Bernal, J. M. (1984). Iniciación al año litúrgico. Madrid: Cristiandad.

Boff, L. (1979). El rostro materno de Dios. Ensayo interdisciplinar sobre lo femenino y sus formas religiosas. Madrid: Paulinas.

Borges Morán, P. (1960). Métodos misionales en la cristianización de América. Siglo XVI.

Madrid: CSIC, Departamento de misionología española.

Caravias, J. L. (1978). Religiosidad campesina y liberación. Bogotá: Indo-American Press Service.

Cárdenas G., e. (2004). La devoción popular a Nuestra Señora. Los Santos. en Cárdenas G., e. Pueblo y religión en Colombia (1780-1820). Estudio histórico sobre la religiosidad popular de Colombia (Nueva Granada) en las últimas décadas de la dominación española. Bogotá: Archivo Histórico Javeriano.

Concilio ecuménico Vaticano II. (1993). Constituciones. Decretos. Declaraciones (ed. bilingüe). Madrid: BAC.

Conferencia episcopal de Colombia [CeC]. (1969, 15 de ago.). Iglesia ante el cambio. en Conferencias Episcopales de Colombia (Spec, n. 308). Bogotá.

Congregación para el culto divino y la disciplina de los sacramentos. (s.f.). en Directorio sobre la piedad popular y la liturgia. Principios y orientaciones. Bogotá: Departamento de liturgia, CeC.

Congregación para la Doctrina de la Fe. (1986, 22 de mar.). en Instrucción sobre libertad cristiana y liberación.

Congreso Mariológico de Colombia. (1973). María en la religiosidad popular. Ponencias, conclusiones, actas. Bogotá: Paulinas.

Consejo episcopal Latinoamericano [Celam]. (1977). Iglesia y religiosidad popular en América Latina. Ponencias y documento final (encuentro de especialistas. 1976, ago. Bogotá). Bogotá: Secretariado General del Celam. 
Consejo episcopal Latinoamericano [Celam]. (1998). Santuarios, expresión de religiosidad popular. Bogotá: Secretariado General del Celam.

Culto y piedad mariana hoy. La exhortación "Marialis Cultus". (1978). en Estudios marianos (vol. XLIII). Madrid: Sociedad Mariológica española.

Danemarie, J. y Revilla, F. (1960). Historia del culto de la Santísima Virgen y sus apariciones. Andorra: Casal I Vall.

De Castells Tejón, J. M. (2011). Los siete rostros de María. La Virgen, la Iglesia y la mujer. Bogotá: Intermedio.

De Santa Teresa, S. (1942). Orígenes de la devoción a la Santísima Virgen en Colombia y Nomenclator Mariano de los descubridores y pobladores de la América Española, Medellín: Bedout.

De Santa Teresa, S. (1951). Vírgenes conquistadoras que Santa Teresa envió a las Américas: La Purísima Concepción y Nuestra Señora del Carmen. Historia documentada de estas imágenes y del desarrollo de su culto y devoción en Iberoamérica. San Sebastián: Vitoria.

Diario Oficial. (1985, 30 de ago.) 2476.

El Espectador (1985, 25 de sep).

Farrell, G. T. (1982). María en la evangelización de la cultura latinoamericana. Revista Medellín, 8(32), 534-539.

Galilea, S. (1968). Presupuesto para una pastoral de santuarios. en Galilea, S. Para una pastoral latinoamericana (pp. 147-163). México D. F.: Paulinas.

Galilea, S. (1976). María en la pastoral popular. Dallas, TX: Paulinas.

Galilea, S. y González, M. (1972). Catolicismo popular. quito: Camino.

Galilea, S. y González, M. (1973). Pastoral de santuarios. quito: Camino.

Grabar, A. (1985). Las vías de la creación en la iconografía cristiana. Madrid: Alianza.

Gracia, J. A. (1971). Problemas y perspectivas de pastoral litúrgica en los santuarios marianos. Phase, 62, 185-194.

Gutiérrez, G. (1979). Sobre el documento de consulta para Puebla. en Gutiérrez, G. La fuerza histórica de los pobres. Lima: CeP.

Idigoras, J. L. (1982). María y la Iglesia. María, mujer y pobre, arquetipo de la Iglesia, femenina y pobre. Revista Medellín, 8(32), 465-487.

Izquierdo Gallo, M. (1956). Mitología americana. Selección de mitos de América. Madrid: Guadarrama.

Laurentín, R. (1984, 28-31 de may.). Presente y porvenir de la mariología. en I Simposio de Teología y Evangelización. La figura de María (pp. 49-55). León: Santuario 
de la Virgen del Camino (Trabajos originalmente publicados en Ciencia Tomista. [1895]. 112, 1-228).

Llano Ruiz, A. (1982). Orientación de la religiosidad popular en Colombia. Devociones cristológicas, marianas, a los santos y a los difuntos. Medellín: Bedout.

María en la Religiosidad popular. Ponencias. Conclusiones. Actas. (1973). en Primer Congreso Mariológico de Colombia. Bogotá.

Martín Velasco, J. (1984, 28-31 de may.). Para vivir la devoción mariana. en I Simposio de Teología y Evangelización. La figura de María (pp. 125-135). León: Santuario de la Virgen del Camino (Trabajos originalmente publicados en Ciencia Tomista. [1895]. 112, 1-228).

Mesanza, A. (1934). La coronación de Nuestra Señora del Rosario de Chiquinquirá. Caracas: Sur América.

Mesanza, A. (1950). Célebres imágenes y santuarios de Nuestra Señora en Colombia. Chiquinquirá: Imprenta de Veritas.

Moliner, J. M. (1974). Espiritualidad medieval. Los mendicantes. Burgos: Monte Carmelo.

Mora Díaz, F. (1945). Historia de los santuarios marianos de Colombia. Bogotá: Taller Gráfico Mundo al Día.

Moreno, I. (1985). Cofradías y hermandades andaluzas. Estructura, simbolismo e identidad. Sevilla: Andaluces Unidas.

Müller, A. (1985). Reflexiones teológicas sobre María, Madre de Jesús. La mariología en perspectiva actual. Madrid: Cristiandad.

Osuna, A. (1984, 28-31 de may.). el misterio de María y la eclesiología de comunión. Reflexiones sobre el significado del misterio de María para la Iglesia. En I Simposio de Teología y Evangelización. La figura de María (pp. 95-124). León: Santuario de la Virgen del Camino (Trabajos originalmente publicados en Ciencia Tomista. [1895]. 112, 1-228).

Pacheco, J. M. (1975). La consolidación de la Iglesia. Siglo XVII. en Historia extensa de Colombia (vol. XII). Bogotá: Lerner.

Pozo, C. (s. f.). La devoción mariana en el contexto teológico, particularmente cristológico y eclesiológico, en europa en los siglos XVII y XVIII. en Archivo Teológico Granadino, 46(a983), 207-241.

Prien, H. J. (1985). La historia del cristianismo en América Latina. Salamanca: Sígueme.

Primer encuentro de Rectores de Santuarios del Cono Sur. (s. f.) Declaración de Caacupé. 
Puebla. Conclusiones. (1979). en III Conferencia General del Episcopado Latinoamericano. Bogotá: Conferencia episcopal de Colombia.

Ramírez Uribe, L. (1979). La práctica y difusión del Rosario en la Colombia del siglo XVI. Theológica Xaveriana, 29.

Restrepo, H. (1972). La religión de la antigua Antioquia. Estudio teológico-pastoral sobre Tomás Carrasquilla. Medellín: Bedout.

Romabel, L. e. (1980). La mujer y el Pueblo de Dios. María, mujer profética. Solidaridad, 13.

Rubio, M. (1984). el rostro cristiano de María. ¿Cómo hablar de María al hombre actual? Razón y fe, 1028, 475-488.

Revista Medellín. (1980). 6, (23), 435-437.

Revista Medellín. (1981). 7, (28), 572-574.

Salado Martínez, D. (1980). Religiosidad mágica. Estudio crítico-fenomenológico sobre la interferencia magia-religión. Salamanca: San esteban.

Santo Domingo. Conclusiones. (1992). en IV Conferencia General del Episcopado Latinoamericano. Bogotá: Conferencia episcopal de Colombia.

Sastoque Poveda, L. F. (2008). Historia de Nuestra Señora del Rosario de Chiquinquirá (Biblioteca Dominicana 22). Bogotá: OP Comunicaciones.

Seladoc-equipo, (1976). Religiosidad popular. Salamanca: Sígueme.

Téllez, L. F. (2005). Una luz en el camino. Santuario de la Virgen del Rosario. ChiquinquiráColombia. Bogotá: Centro Don Bosco.

Vargas Ugarte, R. (1956). Historia del culto de María en Iberoamérica y de sus imágenes y santuarios más celebrados (2 vols). Madrid: Talleres Gráficos Jura.

zuluaga, F. (1977). La religiosidad popular en Colombia. Bogotá: Universidad Javeriana. 
